УДК 378.14

DOI: https://doi.org/10.26642/ten-2020-1(85)-115-120

П.П. Грабовський, к.пед.н., ст. викладач

Комунальний заклад «Житомирський ОІППО» Житомирської обласної ради

\title{
Інфологічна модель бази даних інформаційної системи моніторингу процесу підвищення кваліфікації педагогів
}

\begin{abstract}
У статті зазначено матеріали, щзо стосуються проєктування інформаційної системи моніторингу прочесу підвищення кваліфікащї педагогічних працівників у закладі післядипломної педагогічної освіти. Встановлено, щзо реалізація иієї системи - ие об'єктивна необхідність, яка обумовлена реформуванням діяльності освітніх закладів та доцільністю автоматизаціі оиінювання якості надання відповідних послуг для швидкого прийняття управлінських рішень щцодо регулювання $і$ корекції навчального прочесу. Для вирішення зазначеної проблеми, у межах иьього дослідження, на основі здійсненого аналізу відповідної науково-методичної літератури, побудовано інфологічну модель бази даних, щзо є ядром інформаційної системи моніторингу прочесу підвищення кваліфікації педагогів у закладі післядипломної педагогічної освіти. Зокрема, визначено перелік основних сутностей, відповідних їм атрибутів та відномень між ними. Уточнено вибірки даних, щзо можуть бути реалізовані на основі наданої моделі розглядуваноі предметної області. В иілому побудована інфологічна модель бази даних відповідноі інформаційної системи моніторингу має забезпечити підвищення якості навчального процесу у закладі післядипломної педагогічної освіти за рахунок автоматизачії планування курсів підвищення кваліфікачї педагогів відповідно до наявних потреб, здійснення аналізу результатів навчальної діяльності слухачів за допомогою методів математичної статистики. Разом з тим, у публікації визначено, щзо подальші дослідження можуть стосуватися розробки даталогічноі моделі бази даних розроблюваної інформаційної системи моніторингу та добору відповідного програмного забезпечення для реалізації клієнт-серверної технології обміну даних.
\end{abstract}

Ключові слова: інформаційна система; база даних; інфологічна модель; моніторинг; підвищення кваліфікащіi.

Актуальність теми. Реформування діяльності освітньої галузі, що відбувається наразі в Україні, та системи післядипломної педагогічної освіти (ППО) зокрема, обумовлює необхідність здійснення моніторингу процесу підвищення кваліфікації працівників закладів загальної середньої (33СО) та дошкільної освіти (ЗДО). Це забезпечить спостереження й аналіз реалізації відповідного навчального процесу в закладах ППО для виявлення проміжних і кінцевих результатів, факторів, які на них вплинули. В цілому це сприятиме прийняттю відповідних управлінських рішень щодо регулювання і корекції освітнього процесу для забезпечення його якості. Разом з тим, ефективність здійснення моніторингу, своєчасність впровадження необхідних змін залежить від автоматизації опрацювання наявних даних, що стосуються діяльності закладу ППО. Зазначене обумовлює доцільність застосування відповідних програмних засобів, зокрема спеціалізованих інформаційних систем (IC).

Аналіз останніх досліджень та публікацій, на які спирається автор. Необхідно зауважити, що сьогодні є діючі IC моніторингу діяльності закладів освіти. Зокрема, загальнодержавна інформаційновиробнича система «Освіта», що забезпечує побудову єдиного інтегративного інформаційного середовища України в галузі освіти та являє собою комплекс адміністративних, правових, програмних та апаратно-технічних засобів; а також інформаційна система управління освітою - «Україна. ICУО», що консолідує дані із ЗСО і ЗДО та генерує обов'язкові для цих закладів форми звітності. Моніторинг організації і здійснення освітнього процесу в закладах вищої освіти (3ВО) наразі реалізовується на основі IC «Конкурс» (оперативне інформування абітурієнтів про кількість поданих та прийнятих заяв на навчання до ЗBO III-IV рівнів) та програмного забезпечення ПП «Політек-СОФТ»: «Деканат» - пакет програм для автоматизації планування та обліку навчального процесу; «ПС-Абітурієнт» (автоматизує діяльність приймальної комісії); «Колоквіум» - призначений для автоматизації тестування студентів, а також для всебічного аналізу отриманих результатів та генерації звітів тощо.

Водночас для системи ППО, що відповідно до чинного Закону України «Про вищу освіту» [1] забезпечує підвищення кваліфікації педагогічних працівників, наразі не існує спеціалізованих інформаційних систем для моніторингу освітнього процесу на рівні навчального закладу.

Визначеної проблеми стосується значна кількість наукових праць, серед яких вирізняємо роботи В.С. Авраменко, В.Ю. Бикова, Д.М. Бодненка, П.П. Грабовського, К.Р. Колос, М.С. Львова, В.В. Олійника, В.С. Понамаренка, А.В. Співаковського та інших. 
Науковцями визначено сутність базових понять [2-6], що знайшли своє відображення у нормативних документах [1, 7]; описано структурні елементи, класифікацію, тенденції розвитку інформаційних систем, методологію та технологію їх розробки $[2,6]$; пропонується організація процесу моніторингу освітньої діяльності навчального закладу [3]; описано управління або підтримка науково-освітньої діяльності навчального закладу з використання IC $[4,8]$; висвітлено тенденції розвитку післядипломної педагогічної освіти в умовах реформування [5]; запропоновано організацію комп'ютерно-орієнтованого навчального середовища закладу післядипломної педагогічної освіти [9], складовим елементом якого має бути інформаційна система моніторингу процесу підвищення кваліфікації педагогів.

Крім того, у [10] визначено базові вимоги та концептуальні положення проєктування та реалізації такої системи: мету, завдання, принципи розробки, очікувані результати впровадження, загальну структуру, етапи реалізації тощо. Зокрема, поняття інформаційної системи моніторингу процесу підвищення кваліфікації педагогів визначається як «комплекс програмно-технічних засобів автоматизації зберігання, розповсюдження, аналізу даних щодо організації і результатів цього процесу та прийняття відповідного управлінського рішення 3 його регулювання i корекції» [10]. Завдання, які мають вирішуватися за допомогою розроблюваної IC, такі: покращення ефективності процесу підвищення кваліфікації педагогів за допомогою інформаційної підтримки задач прогнозування і планування організації цього процесу; покращення якості здійснення процесу підвищення кваліфікації у закладі післядипломної педагогічної освіти за рахунок удосконалення інформаційного забезпечення діяльності цієї установи та ії науково-педагогічних працівників; здійснення аналізу результатів навчальної діяльності слухачів курсів підвищення кваліфікації на основі методів математичної статистики. Серед принципів розробки виділено такі: науковості, розвитку, системності, стандартизації, сумісності, ефективності, єдиного введення та багаторазового використання первинних даних, забезпечення інформаційної безпеки i захисту персональних даних тощо. В цілому IC моніторингу процесу підвищення кваліфікації педагогів це багатокористувацька, веборієнтована інформаційно-довідкова система установи (закладу ППО), структура якої організована за клієнт-серверною архітектурою. Ядром проєктованої IC є сервер бази даних та сайт як інтерфейс віддаленого доступу визначених користувачів: «Педагог регіону», «Викладач», «Куратор курсів», «Працівник адміністрації», «Адміністратор IC». Також важливим етапом реалізації визначено проєктування відповідної бази даних (БД).

Насамперед зазначене передбачає розробку інфологічної моделі - концептуальної схеми бази даних, що надалі може трансформуватися у відповідну модель даних: ієрархічну, мережеву, реляційну тощо.

Метою статті $\epsilon$ побудова інфологічної моделі бази даних інформаційної системи моніторингу процесу підвищення кваліфікації педагогів у закладі післядипломної педагогічної освіти.

Викладення основного матеріалу. Конструктивними елементами інфологічної моделі є «сутності» (основні об'єкти певної предметної області - частини реальності, дані про яку мають бути відображені у БД), «зв'язки» між ними (відображають існуючі відношення), а також «атрибути» - виокремлені характеристики «сутності».

Предметною областю нашого дослідження $\epsilon$ процес організації та здійснення підвищення кваліфікації педагогічних працівників ЗСО та ЗДО у закладі ППО. Наразі цей процес реалізується відповідно до чинної постанови № 800 Кабінету Міністрів України від 21 серпня 2019 року [11].

Зокрема, джерелами фінансування підвищення кваліфікації педагогічних працівників можуть бути кошти державного, місцевих бюджетів, фізичних та/або юридичних осіб, закладу освіти, де працює педагог, або його власні. Крім того, є обов'язковим укладання договору між замовником послуги підвищення кваліфікації та суб'єктом (організацією), де це має здійснюватися відповідно до затвердженої програми. Програма підвищення кваліфікації містить дані про іiі розробника (розробників), найменування, мету, напрям (наприклад, розвиток професійної, управлінської, цифрової, мовленнєвої, інклюзивної компетентностей тощо), зміст, обсяг (тривалість), форму навчання; про особу (осіб), які виконують програму - викладачів (рівень освіти, категорія, науковий ступінь, педагогічне/вчене звання, місце та/або досвід роботи тощо); розподіл годин за видами діяльності (консультація; аудиторна, практична, самостійна і контрольна робота тощо); графік освітнього процесу; документ, що видається за результатами підвищення кваліфікації. В цьому документі має бути зазначено повне найменування суб'єкта підвищення кваліфікації, тема (напрям, найменування), обсяг (тривалість) підвищення кваліфікації; прізвище, ім'я та по батькові особи, яка підвищила кваліфікацію; опис досягнутих результатів навчання; дата видачі та обліковий запис документа. В цілому працівники закладів середньої освіти мають здійснювати підвищення кваліфікації кожен рік в обсязі 150 годин за 5 років, а працівники закладів дошкільної освіти - 120 годин одноразово, але не рідше ніж 1 раз на 5 років.

Тому основними сутностями нашої предметної області визначимо: «договір», «слухач» (особа, яка отримує додаткові чи окремі освітні послуги, у тому числі й за програмами післядипломної освіти, зокрема проходить підвищення кваліфікації [1]), «викладач», «навчальна програма», «документ представлення результатів навчання». 
Для сутності «договір» виділяємо такі атрибути, як «номер», «дата укладання»; «замовник» (керівник закладу освіти, де працює педагог, чи сам педагог, який потребує підвищення кваліфікації) та «контактні дані» (номер телефону, електронна пошта тощо); «оплата» (кошти державного, місцевих бюджетів, фізичної або юридичної особи тощо); «заклад освіти» (визначає, де працює педагог); «область», «район, ОТГ» (вказують, де знаходиться заклад освіти); «навчальний рік» (період, у який буде здійснюватися підвищення кваліфікаціі); «загальна кількість осіб» (договір може бути укладений між суб'єктом підвищення кваліфікації та керівником закладу освіти для надання послуг групі педагогів - працівникам закладу освіти). Ключовим атрибутом (однозначно встановлює представника відповідної сутності) визначаємо номер договору.

Для уточнення розподілу слухачів за спеціалізацією - шкільному предметові (учитель математики, фізики тощо) або посадових обов'язків (вихователь групи продовженого дня, заступник директора 3 навчальної роботи тощо) виділяємо окрему сутність «додаток до договору», атрибутами якої є «номер договору», «назва спеціалізації» та «кількість осіб».

Перелік спеціалізацій, за якими суб'єкт підвищення кваліфікації у певному навчальному році може надавати свої послуги, - це відповідний атрибут однієї із основних сутностей «навчальна програма». Іншими характеристиками зазначеної сутності $\epsilon$ «назва програми» (ключовий атрибут), «мета», «напрям», «компетентності» (що будуть розвиватися у слухачів), «загальний обсяг годин», «форма навчання», «навчальний рік», «вартість надання освітньої послуги», «документ, що видається за результатами навчання», «розробник програми». Додатковою сутністю визначаємо «зміст навчання», що має такі атрибути: «навчальна програма», «тема заняття». Останній із названих атрибутів відображає окрему однойменну сутність, що стосується змісту навчання конкретного заняття, яке підготував викладач.

Характеристиками сутності «викладач» можуть бути прізвище, ім'я та по батькові, дата народження, освіта, спеціалізація, контактні дані, науковий ступінь та звання тощо. Додатковими сутностями до зазначеної будуть:

- «навантаження» - «назва посади» (ключовий атрибут), «дата встановлення навантаження», «мінімальна кількість годин», «максимальна кількість годин» (за необхідності з деталізацією яких саме годин - лекційних, практичних або інших видів занять);

- «посада викладача» - «викладач», «назва посади», «назва кафедри», «дата призначення», «номер наказу».

Вирізнення останньої із названих сутностей обумовлено можливістю в повному обсязі зберігати дані про відповідні професійні зміни, що відбуваються у викладача під час роботи у закладі ППО.

Сутність «теми занять» може мати такі атрибути: «викладач», «назва заняття» (ключовий атрибут), «конспект заняття», «кількість годин», «дата представлення» тощо.

Для збереження даних щодо планування підвищення кваліфікації груп слухачів за різними програмами на навчальний рік виокремлюємо сутність «календарний план підвищення кваліфікації» із такими атрибутами: «дата початку навчання», «дата закінчення навчання», «навчальна програма», «куратор», «номер навчальної групи» (ключовий атрибут), «максимальна кількість слухачів». Крім того, для представлення розподілу занять навчальної групи слухачів за датою їх проведення додаємо у перелік сутностей «розклад занять» із характеристиками «навчальна група», «тема заняття», «дата проведення», «номер заняття» (зокрема, якщо заняття проводяться у формі пар, то цей атрибут відповідає номеру пари у певний навчальний день).

Представник сутності «слухач» має такі характеристики: «прізвище», «ім'я», «по батькові», «рік народження» (ключові атрибути); «номер договору», відповідно до якого слухач зареєструвався на підвищення кваліфікації, що дозволить уточнити замовника освітньої послуги, заклад освіти, де працює педагог, адміністративну одиницю, де знаходиться цей заклад, тощо; «номер групи», що забезпечить визначення дати початку та закінчення навчання, навчальну програму, спеціалізацію, куратора навчальної групи тощо; «стаж роботи», «освіта», «кваліфікаційна категорія» (відображає наявний професійний рівень педагога).

Додаткові сутності, що стосуються результатів навчальної діяльності слухача, «випускна робота», «відвідування», «документ представлення результатів навчання». Уточнимо відповідні атрибути для зазначених сутностей:

- «випускна робота» - «слухач» (ключовий атрибут), «тема випускної роботи», «текст випускної роботи», «рецензент», «висновок рецензента», «рецензія»;

- «відвідування» - «слухач», «дата відсутності», «номер заняття»;

- «документ представлення результатів навчання» - «слухач», «номер документа», «дата видачі».

Схематичне зображення проєктованої бази даних наведено на рисунку 1, ключові атрибути позначено символом «*». Крім того, на діаграмі відображено зв'язки між атрибутами визначених сутностей, а також їх типи. 


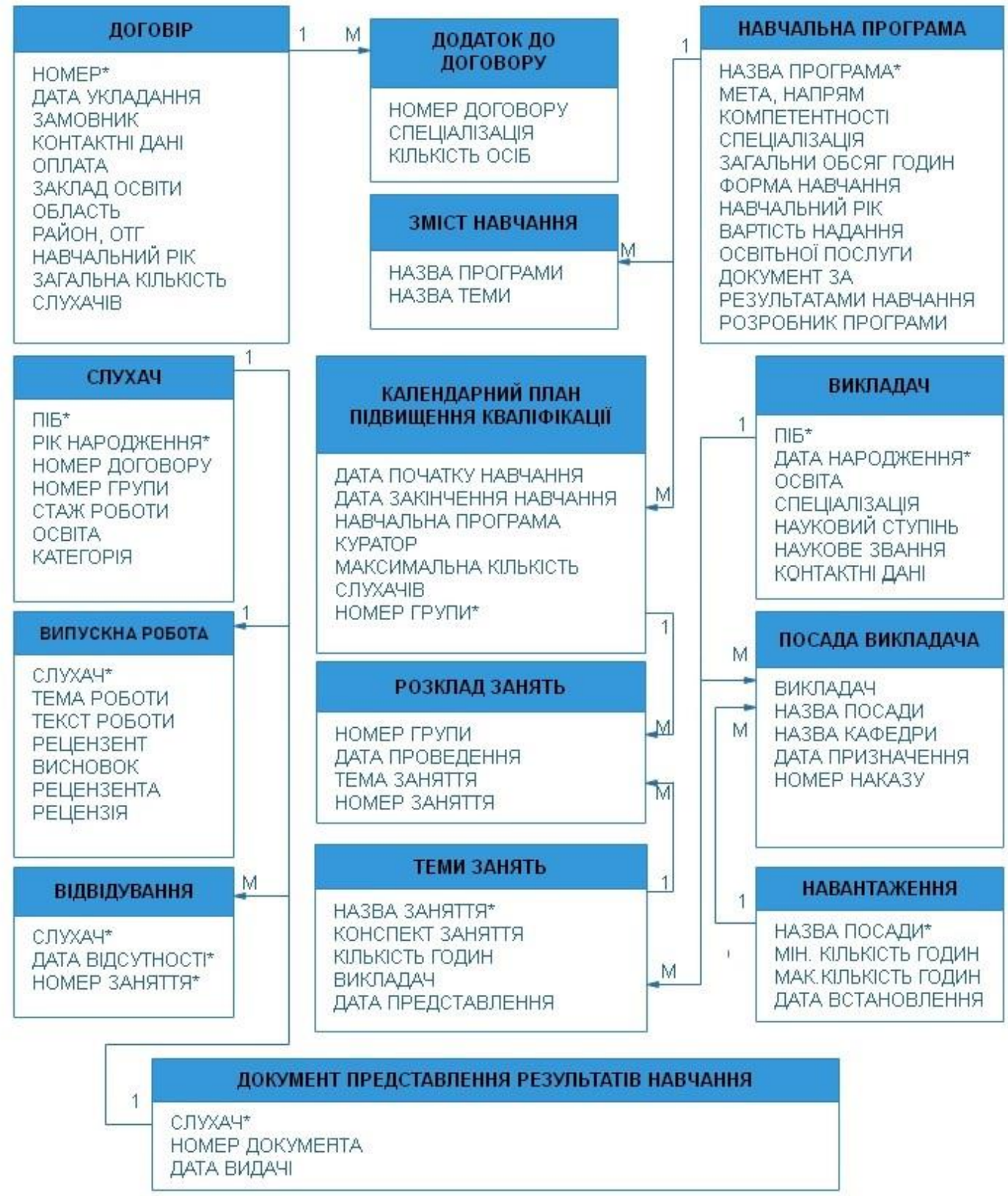

Рис. 1. Інфологічна модель бази даних інформаційної системи моніторингу процесу підвищення кваліфікації педагогів

На основі запропонованої моделі бази даних можливе здійснення моніторингу процесу підвищення кваліфікації за допомогою реалізації таких запитів і звітів, як:

- визначення загальної кількості слухачів, які здійснили підвищення кваліфікації у закладі ППО, та за визначений навчальний рік зокрема;

- розподіл слухачів за джерелами оплати наданої закладом ППО освітньої послуги;

- визначення кількості та типу (ЗДО, ЗСО тощо) освітніх закладів, працівники яких підвищують кваліфікацію у закладі ППО;

- розподіл слухачів за спеціалізаціями, рівнем освіти, стажем роботи, кваліфікаційною категорією в цілому та за певний навчальний рік зокрема;

- визначення важливих для слухачів навчальних занять за рівнем їх відвідування;

- відслідковування якості випускних робіт слухачів та дотримання ними академічної доброчесності, зокрема самоплагіату, внаслідок формування електронного репозитарію відповідних текстів; 
- визначення обсягу годин підвищення кваліфікації певного слухача за відповідний проміжок часу: навчальний рік, декілька років, п’ятирічний термін тощо;

- порівняння результатів навчальної діяльності слухача у розрізі кваліфікаційної категорії: спеціаліст, друга, перша, вища категорії;

- порівняння результатів навчальної діяльності залежно від форми навчання: очна, заочна, очнодистанційна;

- порівняння результатів навчальної діяльності у розрізі навчальних програм підвищення кваліфікації;

- визначення можливого комбінування різних навчальних програм для забезпечення ефективного здійснення підвищення кваліфікації слухачем 3 гармонійним розвитком його професійних компетентностей і дотримання вимог постанови № 800 Кабінету Міністрів України [11];

- порівняння результатів навчальної діяльності залежно від розташування слухачів по адміністративних одиницях регіону;

- визначення актуальної форми навчання (очної, очно-дистанційної, заочної), календарних періодів, внаслідок здійснення аналізу розподілу слухачів відповідно зазначених критеріїв за декілька років;

- відслідковування спеціалізації, спектра вчених ступенів та вчених звань, посад викладацького складу закладу ППО, що опосередковано визначатиме якість надання освітніх послуг суб'єктом підвищення кваліфікації;

- моніторинг планування для викладача та виконання ним аудиторного й позааудиторного навчального навантаження;

- відслідковування змін у тематиці навчальних занять певного викладача за необхідний проміжок часу;

- $\quad$ виключення можливості запису викладача на один і той же номер заняття у різні навчальні групи слухачів певної дати їх проведення;

- визначення середньостатистичного слухача (вік, стать, освіта, стаж, кваліфікаційна категорія розташування навчального закладу, тип оплати освітньої послуги, відвідуваність занять тощо) для ефективного планування процесу підвищення кваліфікації педагогів у майбутньому.

В цілому зазначена інфологічна модель бази даних інформаційної системи моніторингу процесу підвищення кваліфікації педагогів у закладі післядипломної педагогічної освіти має забезпечити:

- покращення якості цього процесу завдяки автоматизації планування курсів підвищення кваліфікації педагогів відповідно до існуючих потреб та аналізу результатів навчальної діяльності слухачів;

- зменшення часових затрат працівників закладу післядипломної педагогічної освіти на підготовку документів внутрішньої звітності (навчальної програми, журналу обліку курсів підвищення кваліфікації; розкладу занять тощо) за рахунок одноразового введення відповідних даних та їх багаторазового використання;

- зменшення часових затрат адміністрації закладу на моніторинг документації внутрішньої звітності;

- підвищення якості планування спільної діяльності закладу ППО з районними методичними кабінетами та відповідними представниками утворених об'єднаних територіальних громад регіону щодо професійного розвитку педагогів у міжкурсовий період завдяки проведенню різностороннього аналізу результатів навчальної діяльності слухачів за допомогою методів математичної статистики тощо.

Висновки та перспективи подальших досліджень. Отже, проєктування та реалізація інформаційної системи моніторингу процесу підвищення кваліфікації педагогічних працівників - нагальна потреба сьогодення, обумовлена здійсненням реформування освітньої галузі та необхідністю оцінки якості наданих послуг навчальними закладами. Зокрема і закладами системи післядипломної педагогічної освіти, для яких наразі не існує спеціалізованих IC.

Для вирішення

наявної проблеми у межах нашого дослідження було розроблено інфологічну модель бази даних відповідної інформаційної системи моніторингу процесу підвищення кваліфікації педагогів у закладі ППО. Зокрема, визначено перелік основних сутностей («договір», «слухач», «відвідування», «документ представлення результатів навчання», «навчальна програма», «зміст навчання», «календарний план підвищення кваліфікації», «розклад занять», «викладач», «посада викладача», «навантаження» тощо), уточнено їх атрибути та відповідні зв'язки між ними.

Подальші дослідження можуть стосуватися розробки даталогічної моделі БД інформаційної системи моніторингу процесу підвищення кваліфікації педагогічних працівників та добору відповідного програмного забезпечення (систем управління БД) для реалізації клієнт-серверної технології обміну даних у середовищі IC. 


\section{Список використаної літератури:}

1. Закон України «Про вищу освіту» [Електронний ресурс]. - Режим доступу : http://zakon3.rada.gov.ua/laws/show/1556-18/page5.

2. Пономаренко В.С. Інформаційні системи в управлінні персоналом / В.С. Пономаренко, І.В. Журавльова, І.Л. Латишева. - Харків : ХНЕУ, 2008. - 337 с.

3. Моніторинг навчальної діяльності : навчальний посібник / Д.М. Бодненко, О.Б. Жильциов, О.Л. Лещчинський, Н.П. Мазур. - К. : Київський університет імені Бориса Грінченка, 2014. - 276 с.

4. Львов М.C. Інформаційна система управління вищим навчальним закладом як платформа реалізації управління академічним процесом / М.С. Львов, О.В. Співаковський, Д.С. Щедролосьєв // Комп’ютер у школі та сім’ї. - 2007. - № 2. - С. 3-6.

5. Олійник B.B. Тендеції розвитку післядипломної освіти в умовах трансформації суспільства / B.B. Олійник // Теорія і практика управління соціальними системами. - 2013. - № 1. - С. 56-66.

6. Авраменко В.C. Проектування інформаційних систем : навчальний посібник / B.C. Авраменко, A.C. Авраменко. - Черкаси : Черкаський національний університет ім. Б.Хмельницького, $2017 .-434$ с.

7. Перелік Національних стандартів України для створення, впровадження та супроводження автоматизованих і інформаційних систем // Національна бібліотека України імені I.В. Вернадського [Електронний ресурс]. - Режим доступу : http://nbuv.gov.ua/node/1469.

8. Биков В.Ю. Корпоративні інформаційні системи підтримування науково-освітньої діяльності на базі хмаро орієнтованих сервісів / В.Ю. Биков, О.М. Спірін, М.П. Шишкіна // Проблеми та перспективи формування національної гуманітарно-технічної еліти : збірник наукових праць. - 2015. - № 47. - С. 93-121.

9. Колос К.P. Теоретико-методичні засади проектування і використання комп'ютерно орієнтованого навчального середовища закладу післядипломної педагогічної освіти : дис. на здобуття наук. ступеня д.пед.н., спец. : 13.00 .10 / К.Р. Колос. - Київ, 2017. - 453 с.

10. Грабовський П.П. Проєктування інформаційної системи моніторингу процесу підвищення кваліфікації педагогів / П.П. Грабовський // Інформаційні технології та засоби навчання. - 2019. - Т. 73, № 5. - С. $206-218$.

11. Деякі питання підвищення кваліфікації педагогічних та науково-педагогічних працівників : постанова Кабінету Міністрів України від 19.08.2019 № 800 [Електронний ресурс]. - Режим доступу : https://zakon.rada.gov.ua/laws/show/800-2019-\%D0\%BF.

\section{References:}

1. «Pro vyshhu osvitu», Zakon Ukrai'ny, [Online], available at: http://zakon3.rada.gov.ua/laws/show/1556-18/page5

2. Ponomarenko, V.S., Zhuravl'ov, I.V. and Latisheva, I.L. (2008), Informaczijni systemy v upravlinni personalom, KhNEU, Kharkiv, 337 p

3. Bodnenko, D.M., Zhyl'cov, O.B., Leschins'kyj, O.L. and Mazur, N.P. (2014), Monitoryng navchal'noi' dijal'nosti, navchal'nyj posibnyk, Kyi'vskyj universytet imeni Borisa Grinchenka, Kyi'v, 276 p.

4. L'vov, M.S., Spivakovs'kyj, O.V. and Schedrolos'ev, D.Ye. (2007), «Informacijna systema upravlinnaj vyshhim navchal'nym zakladom jak platforma realizaciji upravlinnja akademichnym procesom», Komp'juter u shkoli ta simi', No. 2, pp. 3-6.

5. Olijnyk, V.V. (2013), «Tendecii' rozvytku pislyadyplomnoji osvity v umovah transformacii' suspil'stva», Teorija $i$ praktyka upravlinnja social'nymy systemamy, No. 1, pp. 56-66.

6. Avramenko, V.S. and Avramenko, A.S. (2017), Proektuvannja informacijnyh system, navchal'nyj posibnyk, Cherkas'kyj nacional'nyj universytet im. B. Khmel'nyc'kogo, Cherkasy, 434 p.

7. «Perelik Nacional'nykh standartiv Ukrajiny dlja stvorennja, vprovadzhennja ta suprovodzhennja avtomatyzovanyh i informacijnyh system», Nacional'na biblioteka Ukrai'ni imeni I.V. Vernads'kogo, [Online], available at: http://nbuv.gov.ua/node/1469

8. Bykov, V.Yu., Spirin, O.M. and Shyshkina, M.P. (2015), «Korporatyvni informacijni systemy pidtrymuvannja naukovo-osvitn'oi' dijal'nosti na bazi hmaro orijentovanyh servisiv», Problemy ta perspektyvy formuvannja nacional'noji gumanitarno-tekhnichnoi' elity, zbirnyk naukovyh prac', No. 47, pp. 93-121.

9. Kolos, K.R. (2017), Teoretyko-metodichni zasady proektuvannja $i$ vykorystannja kompjuterno orijentovanogo navchal'nogo seredovyscha zakladu pisljadyplomnoi' pedagogichnoi' osvity, Ph.D. Thesis, spec. 13.00.10, Kyi'v, 453 p.

10. Grabovs'kyj, P.P. (2019), «Projektuvannja informacijnoi' systemy monitoryngu procesu pidvyschennja kvalifikacii' pedagogiv», Informacijni tehnologii' ta zasoby navchannja, Vol. 73, No. 5, pp. 206-218.

11. Kabinet Ministriv Ukrajiny (2019), Dejaki pytannja pidvischennja kvalifikacii' pedagogichnyh ta naukovopedagogichnyh pracivnykiv, postanova vid 19.08.2019 No. 800, [Online], available at: https://zakon.rada.gov.ua/laws/show/800-2019-\%D0\%BF

Грабовський Петро Петрович - кандидат педагогічних наук, старший викладач кафедри педагогіки та андрагогіки Комунального закладу «Житомирський ОІППО» Житомирської обласної ради.

Наукові інтереси:

- інформаційні системи;

- бази даних;

- комп’ютерно орієнтоване навчальне середовище. 